\title{
Partisipasi Petani dalam Kegiatan Peningkatan Produksi Sayuran dan Tanaman Obat melalui Kawasan Aneka Cabai Di Kecamatan Kismantoro Kabupaten Wonogiri
}

\section{Farmers' Participation in Activities to Increase Vegetable and Medicinal Plant Production through Various Chili Areas in Kismantoro District, Wonogiri Regency}

\author{
Nurhudha Agung Prasetyo, Eny Lestari, Hanifah Ihsaniyati Program
}

\author{
Studi Penyuluhan dan Komunikasi Pertanian Fakultas Pertanian Universitas Sebelas Maret
}

J1. Ir. Sutami No.36 A Kentingan Surakarta 57126 Telp/Fax (0271) 637457

Email: nurhudha.agung@gmail.com

\begin{abstract}
The aims of this research are to know the farmers' internal factors related to farmer participation in activities to increase vegetable production and medicinal plants through various chili areas, analyze the level of farmer participation in activities to increase vegetable production and medicinal plants through various chili areas, and analyzing the relationship of farmers' internal factors with the level of farmer participation in activities to increase vegetable production and medicinal plants through various chili areas. This research uses quantitative methods with survey techniques. The research location was determined intentionally, namely Kismantoro Subdistrict, with the consideration that the sub-district was the district with the largest land area and production yield in Wonogiri Regency. The research population this time is farmers who are members of farmer groups that receive activities namely 197 farmers. The sampling method was carried out proportionally random sampling, with a sample size of 60 farmers. To test the relationship, rank spearman analysis was used with SPSS version 20. The results showed that the majority of farmers were of productive age, the most formal farmers were elementary school graduates, farmers in the low category, the largest farmer area was 0.51-0, 75 ha, the level of farmer risk taking in the high category, the activeness of farmer membership in the medium category. The level of farmer participation at the planning stage and at the implementation stage is classified as a moderate category, while the level of farmer participation at the utilization stage of the results is classified as high. The internal factors of the farmer who have a significant relationship with the level of farmer participation are age, non-formal education, risk-taking level and liveliness of farmer membership, while the farmers' internal factors that have no relation to farmer participation level are formal education and land tenure.
\end{abstract}

Keywords: Chili, Participation, Increased Production, Farmers

Abstrak: Penelitian ini bertujuan untuk mengetahui faktor internal petani yang berhubungan dengan partisipasi petani dalam kegiatan peningkatan produksi sayuran dan tanaman obat melalui kawasan aneka cabai, menganalisis tingkat partisipasi petani dalam kegiatan peningkatan produksi sayuran dan tanaman obat melalui kawasan aneka cabai dan menganalisis hubungan faktor internal petani dengan tingkat partisipasi petani dalam kegiatan peningkatan produksi sayuran dan tanaman obat melalui kawasan aneka cabai. Penelitian ini menggunakan metode kuantitatif dengan teknik survey. Lokasi penelitian ditentukan secara sengaja yaitu Kecamatan Kismantoro, dengan pertimbangan kecamatan tersebut merupakan kecamatan dengan luas lahan dan hasil produksi paling banyak di Kabupaten Wonogiri. Populasi penelitian kali ini adalah petani yang tergabung dengan kelompok tani yang menerima kegiatan yaitu 197 petani. Metode pengambilan sampel dilakukan secara proporsional random sampling, dengan jumlah sampel 60 petani. Untuk menguji hubungan, digunakan analisis rank spearman dengan SPSS versi 20. Hasil penelitian menunjukkan umur petani mayoritas dalam usia produktif, pendidikan formal petani terbanyak lulusan SD, pendidikan non formal petani dalam kategori rendah, luas lahan petani terbanyak dengan luas 0,51-0,75 ha, tingkat pengambilan resiko petani dalam kategori tinggi, keaktifan keanggotaan petani dalam kategori sedang. Tingkat partisipasi petani pada tahap perencanaan dan pada tahap pelaksanaan tergolong kategori sedang, sedangkan tingkat partisipasi petani pada tahap pemanfaatan hasil tergolong dalam kategori tinggi. Faktor internal petani yang memiliki hubungan signifikan dengan tingkat partisipasi petani adalah umur, pendidikan non formal, tingkat pengambilan resiko dan keaktifan keanggotaan petani, sedangkan faktor internal petani yang tidak memiliki hubungan dengan tingkat partisiapsi petani adalah pendidikan formal dan luas penguasaan lahan.

Kata Kunci: Cabai, Partisipasi, Peningkatan Produksi, Petani 


\section{PENDAHULUAN}

Hortikultura mempunyai peran yang cukup besar dalam pembangunan perekonomian di Indonesia. Direktorat Jendral Hortikultura (2015) mengatakan bahwa pembangunan hortikultura di Indonesia memiliki potensi yang cukup besar karena didukung oleh: payung hukum/ regulasi, keanekaragaman hayati, ketersediaan lahan pertanian, agroklimat (iklim yang sesuai), dukungan teknologi, ketersedian tenaga kerja, ketersedian pasar, dukungan penetapan komoditas prioritas hortikultura, dukungan pengembangan sistem perbenihan hortikultura dan dukungan pengembangan sistem perlindungan hortikultura, dengan banyaknya dukungan dukungan tersebut, prospek komoditas hortikultura di masa mendatang cukup menggembirakan.

Tanaman hortikultura merupakan tanaman potensial yang mempunyai nilai ekonomi tinggi dan memiliki potensi untuk terus dikembangkan. Salah satu tanaman hortikultura yang memiliki potensi baik untuk dikembangkan di Indonesia adalah komoditas cabai besar. Cabai besar (Capsicum annuum L) termasuk dari sekian banyak komoditas pertanian Indonesia yang menjadi pusat perhatian. Saptana et al. (2010) menyatakan beberapa alasan penting pengembangan komoditas cabai besar adalah (1) tergolong sebagai komoditas bernilai ekonomi tinggi, (2) merupakan salah satu komoditas sayuran unggulan nasional, (3) menduduki posisi penting dalam hampir seluruh menu masakan di Indonesia, (4) memiliki prospek ekspor yang baik, (5) mempunyai daya adaptasi yang luas, (6) bersifat intensif dalam menyerap tenaga kerja. Salah satu daerah yang memiliki potensi yang baik dalam budidaya cabai besar di Indonesia adalah Kabupaten Wonogiri.

Kabupaten Wonogiri merupakan daerah yang berada di Provinsi Jawa Tengah yang mempunyai potensi di bidang pertanian yang cukup baik, khususnya komoditas cabai besar. BPS (2017) menyatakan bahawa Kabupaten Wonogiri memiliki areal lahan cabai besar seluas 425 ha. Luasan lahan tersebut sangat potensial untuk pengembangan tanaman cabai. Areal lahan cabai tersebut terbagi dari 25 kecamatan yang berada di Kabupaten Wonogiri yang dimana dapat memproduksi cabai sebanyak 3.800 ton per tahunnya. Kabupaten Wonogiri memiliki beberapa
Kecamatan yang menjadi sentra produksi cabai besar, dari beberapa sentra penghasil cabai besar tersebut, Kecamatan Kismantoro menjadi wilayah terbesar penghasil cabai di wilayah Wonogiri dengan luas lahan mencapai 189 hektare dengan produksi rata rata 11.238 kuintal per tahunnya.

Kegiatan pertanian pada tanaman cabai besar seperti layaknya kegiatan di sub sektor pertanian lainnya pasti tidak luput dari adanya permasalahan. Permasalahan tersebut adalah tidak meratanya produksi cabai setiap tahunnya dan mutu cabai yang kurang baik. Permasalahan ini juga menjadi permasalahan nasional yang dimana terjadi tidak hanya di Kabupaten Wonogiri saja, melainkan di wilayah wilayah lainnya. Ketidak merataan produksi cabai diakibatkan karena banyak petani cabai yang menanam cabai secara musiman, dan belum menanam sepanjang tahun Guna untuk mengatasi permasalahan tersebut Kementrian Pertanian melalui Direktorat Jendral Hortikultura mulai merancang suatu program untuk mengembangkan tanaman hortikultura program tersebut adalah program peningkatan produksi dan nilai tambah produk hortikultura yang mencangkup seluruh komoditas hortiluktura di Indonesia, di dalam program tersebut terdapat 1 kegiaan utama yang bertujuan khusus untuk meningkatkan produksi komoditas cabai besar, kegiatan tersebut adalah peningkatan produksi sayuran dan tanaman obat melalui kawasan aneka cabai. Kegiatan tersebut sudah dilaksanakan sejak tahun 2015 dan bertempat di berbagai kecamatan di Kabupaten Wonogiri, salah satunya adalah di Kecamatan Kismantoro.

Kegiatan Peningkatan Produksi Sayuran dan Tanaman Obat Melalui Kawasan Aneka Cabai dalam keberjalanannya membutuhkan partisipasi petani dalam setiap tahapannya. Partisiapsi petani dibutuhkan karena, tanpa adanya partisipasi maka kegiatan tersebut tidak berjalan dengan optimal. Pentingnya partisipasi dikemukakan oleh Conyers (1991) sebagai berikut: (1) partisipasi masyarakat merupakan suatu alat guna memperoleh informasi mengenai kondisi, kebutuhan, dan sikap masyarakat setempat, yang tanpa kehadirannya program pembangunan serta proyek - proyek akan gagal, (2) bahwa masyarakat akan lebih mempercayai proyek atau program pembangunan jika merasa dilibatkan dalam proses persiapan dan perencanaannya, karena mereka akan lebih mengetahui seluk-beluk proyek 
tersebut dan akan mempunyai rasa memiliki terhadap proyek tersebut (3) bahwa merupakan suatu hak demokrasi bila masyarakat dilibatkan dalam pembangunan masyarakat mereka sendiri.

Berdasarkan kondisi di lapang, partisipasi petani dalam keberjalanan kegiatan masih belum optimal. Hal ini disebabkan karena petani pada proses perencanaan, pelaksanaan dan pemanfaatan hasil kegiatan belum sepenuhnya terlibat, namun data tersebut belum jelas adanya dikarenakan belum ada penelitian yang membahas mengenai hal tersebut. Mengingat partisipasi merupakan suatu hal yang penting dalam keberjalanan kegiatan, oleh karena itulah perlu dilakukan penelitian tentang partisipasi petani dalam kegiatan peningkatan produksi sayuran dan tanaman obat melalui kawasan aneka cabai di Kecamatan Kismantoro Kabupaten Wonogiri

\section{METODE PENELITIAN}

Metode yang digunakan dalam penelitian ini adalah penelitian kuantitatif. Penelitian ini menggunakan teknik survei yang merupakan penelitian yang informasinya dikumpulkan dari responden dengan menggunakan kuisioner. Penentuan lokasi penelitian dilakukan dengan cara sengaja didasarkan dengan tujuan penelitian. Lokasi penelitian yang diambil adalah Kecamatan Kismantoro, Kabupaten Wonogiri dengan pertimbangan daerah tersebut menerima kegiatan serta memiliki luas lahan cabai serta hasil produksi yang paling tinggi diantara kecamatan penerima kegiatan lainnya di Kabupaten Wonogiri, yaitu luas lahan 189 ha dan dengan hasil produksi sebanyak 11.238 kuintal pertahun.

Populasi pada penelitian ini diambil dari petani cabai yang telah menerima kegiatan peningkatan produksi sayuran dan tanaman obat melalui kawasan aneka cabai. Populasi di tentukan dengan secara purposive sampling, yaitu petani cabai yang tergabung dengan kelompok tani yang diambil dari 5 desa yang sudah menerima kegiatan dari total 10 desa yang berada di Kecamatan Kismantoro. Desa tersebut adalah Gesing, Gedawung, Bugelan, Pucung dan Kelurahan Kismantoro. Pemilihan sampel responden dilakukan dengan menggunakan metode proporsional random sampling, dengan jumlah sampel yang akan digunakan dalam penelitian ini adalah 60 orang yang berasal dari 5 kelompok tani dari 5 desa yang telah menerima kegiatan. Jenis data yang digunakan pada penelitian kali ini adalah data kuantitatif dan kualitatif serta sumber data yang digunakan adalah sumber data primer dan sekunder yang diambil dengan cara wawancara, observasi dan dokumentasi. Data pada penelitian ini disajikan dengan skala likert dan untuk menguji hubungan antara faktor internal petani dengan tingkat partisipasi petani digunakan analisis rank spearman dengan SPSS versi 20.

\section{HASIL DAN PEMBAHASAN}

Kegiatan peningkatan produksi sayuran dan tanaman obat melalui kawasan aneka cabai merupakan 1 dari 6 kegiatan utama dari program peningkatan produksi dan nilai tambah produk hortikultura yang telah dilaksanakan sejak Tahun 2015 di berbagai wilayah di Indonesia. Kegiatan peningkatan produksi sayuran dan tanaman obat melalui kawasan aneka cabai terlaksana di 33 provinsi 272 kabupaten/ kota dengan luas lahan aneka cabai seluas 13.500 ha dan dibiayai dengan dana anggaran endapatan Belanja pegara (APBN) melalui dana tugas pembantuan pada satker dinas pertanian provinsi. Daerah yang telah menerima kegiatan ini adalah di Kecamatan Kismantoro Kabupaten Wonogiri. Kecamatan Kismantoro memiliki luas lahan cabai 189 ha dengan hasil produksi $11.238 \mathrm{kw}$ per tahun.

Peningkatan kawasan dilakukan pada lahan yang diusahakan oleh petani sebagai anggota kelompok tani berupa penataan kawasan aneka cabai dengan jenis komoditas yang sudah ditentukan oleh dinas pertanian Kabupaten Wonogiri. Kegiatan ini telah dilaksanakan sejak tahun 2015 di Kecamatan Kismantoro dan diikuti oleh 5 desa/ kelurahan. Pada Tahun 2018 desa/ kelurahan penerima kegiatan adalah Desa Bugelan, Desa Pucung, Desa Gesing, Desa Gedawung, dan Kelurahan Kismantoro. Penerima kegiatan bukanlah seluruh kelompok tani di desa tersebut, melainkan 1 kelompok tani yang telah memenuhi kriteria yang telah ditentukan, kelompok tani tersebut adalah kelompok Tani Langgeng dari Desa Gesing, Ngesti Rejeki dari Desa Gedawung, Ngudi Boga dari desa Bugelan, Tani Maju dari Desa Pucung dan Ngudi Rukun dari Kelurahan 
Kismantoro. Kriteria tersebut adalah (1) penerima manfaat diutamakan kelompok tani/gapoktan/ kelompok wanita tani binaan champion/penggerak yang sudah dan akan menandatangani MOU/ perjanjian kerjasama dengan Direktorat Jenderal Hortikultura dalam rangka menjaga produksi, pasokan dan stabilisasi harga. (2) sanggup menanam pada waktu-waktu tertentu sesuai petunjuk dinas. (3) bersedia berkoordinasi dan mendapatkan pendampingan dan pembinaan dari Dinas dalam mengatur pertanaman aneka cabai diwilayahnya dengan tujuan menstabilkan pasokan sepanjang bulan. (4) diutamakan kelompok yang telah diusulkan melalui e-proposal. (5) kelompok tani/gapoktan dapat menerima bantuan setiap tahun dengan perjanjian

Faktor Internal Petani yang Berhubungan dengan Partisipasi Petani Petani dalam Kegiatan Peningkatan Produksi Sayuran dan Tanaman Obat Melalui Kawasan Aneka Cabai

Faktor internal petani yang dikaji penelitian ini adalah adalah umur, pendidikan formal, pendidikan non formal, luas penguasaan lahan, tingkat pengambilan resiko dan keaktifan keanggotaan petani.

\section{Umur}

Umur yaitu satuan waktu yang mengukur waktu keberadaan hidup petani yang bersangkutan mulai dari lahir sampai pada saat dilakukan penelitian. Mayoritas petani responden di Kecamatan Kismantoro Kabupetan Wonogiri memiliki umur yang masuk dalam kategori produktif berumur 15-64 tahun yaitu 91,67\%. Umur petani mempengaruhi kondisi petani dalam melakukan aktivitas, khususnya aktifitas fisik, contohnya saja pada kegiatan pertanian membutuhkan tenaga yang cukup besar. Umur juga mempengaruhi penerimaan hal-hal baru bagi seorang petani. Petani yang tergolong umur produktif biasanya lebih mudah untuk menerima hal hal baru.

\section{Pendidikan Formal}

Pendidikan formal merupakan jenjang pendidikan sekolah yang penyelenggaraannya tersusun dalam kurikulum yang terorganisir, berjenjang dari rendah sampai tingkat tinggi. Petani responden di Kecamatan Kismantoro masih memiliki pendidikan formal yang rendah yaitu lulusan SD, SMP dan tidak tamat sejumlah $70 \%$ dari responden. kondisi ini terjadi karena petani tidak memiliki biaya yang cukup untuk meneruskan pendidikan ke tingkat yang lebih tinggi dan masih kurangnya kesadaran akan pentingnya pendidikan serta sarana prasarana pendidikan yang terbatas, dimana untuk melanjutkan ke tingkat pendidikan yang lebih tinggi harus menempuh jarak yang jauh dengan transportasi yang masih sulit.

\section{Pendidikan Non Formal}

Pendidikan non formal merupakan pendidikan yang diperoleh petani di luar pendidikan formal, memiliki program yang terencana, dapat dilakukan dimana saja, tidak terikat waktu serta disesuaikan dengan kebutuhan. Pendidikan non formal petani responden di Kecamatan Kismantoro paling banyak dikategorikan dalam kategori rendah yaitu sebanyak 43,33\%. Kurangnya pemahaman petani terhadap manfaat yang didapatkan ketika mengikuti kegiatan pendidikan non formal seperti penyuluhan menyebabkan rendahnya angka keikutsertaan petani dalah kegiatan tersebut. Petani jarang ikut pelatihan dikarenakan hanya kurangnnya minat petani untuk mempelajari hal baru, sedangkan di dalam kegiatan studi banding hanya beberapa petani saja yang dapat mengikuti kegiatan tersebut dikarenakan kegiatan studi banding itu sendiri yang membutuhkan biaya lebih sehingga tudak dapat melibatkan seluruh petani.

\section{Luas Penguasaan Lahan}

Luas penguasaan lahan adalah luas lahan yang diusahakan petani untuk kegiatan usahatani baik itu milik sendiri, menyewa atau menyakap. Rata rata luas penguasaan lahan petani responden di Kecamatan Kismantoro masuk dalam kategori sedang yaitu sebesar $61,67 \%$. Petani yang memiliki lahan sawah sedang, ketika panen nanti hasil yang didapat tidak akan terlalu banyak/tidak akan maskimal. Hal tersebut akan mempengaruhi pendapatan petani jika petani tersebut hanya memiliki pekerjaan di bidang pertanian saja.

\section{Tingkat Pengambilan Resiko}

Resiko diartikan sebagai peluang akan terjadinya suatu kejadian buruk akibat suatu tindakan. Makin tinggi tingkat ketidakpastian 
suatu kejadian, makin tinggi pula resiko yang disebabkan oleh pengambilan keputusan itu. Tingkat pengambilan resiko yang dilakukan oleh petani responden paling banyak pada kategori tinggi yang berjumlah $43,33 \%$. Petani responden berani mengambil resiko lebih karena petani menginginkan perubahan kearah yang lebih baik. Petani berani mengeluarkan modal lebih tinggi dikarenakan petani juga ingin hasil dari budidaya cabainya bagus sehingga bisa mendapatkan keuntungan lebih dari kegiatan budidaya. Begitu juga dengan meluangkan waktu lebih dan menerapkan inovasi baru.

\section{Keaktifan Keanggotaan Petani}

Keaktifan keanggotaan petani adalah tinggi rendahnya keterlibatan petani dalam kegiatan kelompok taninya maupun organisasi lainya yang berhubungan dengan bidang pertanian. Keaktifan keanggotaan petani ini diukur dari keikutsertaan petani atau anggota kelompok dalam hal mengikuti pertemuan, membantu administrasi, pengadaan saprodi, dan menyumbang materil kepada kelompok tani. Keaktifan keanggotaan petani responden di Kecamatan Kismantoro paling banyak pada kategori sedang yaitu sebanyak 43,33\%. Petani responden cukup mengikuti setiap kegiatan yang dilakukan di kelompok. Jika petani memiliki kesadaran yang baik, maka nantinya akan berdampak baik juga terhadap keberjalanan kegiatan kelompok tani.

\section{Tingkat Partisipasi Petani dalam Kegiatan Peningkatan Produksi Sayuran dan Tanaman Obat Melalui Kawasan Aneka Cabai.}

Tingkat partisipasi petani dalam penelitian ini adalah keikutsertaan petani dalam kegiatan peningkatan produksi sayuran dan tanaman obat melalui kawasan aneka cabai yang dilihat dari tahap perencanaan, pelaksanaan, dan pemanfaatan hasil.

\section{Tingkat Partisipasi pada Tahap Perencanaan}

Partisipasi petani pada perencanaan adalah peran serta petani dalam proses perencanaan kegiatan peningkatan produksi sayuran dan tanaman obat melalui kawasan aneka cabai yang terdiri dari intensitas menghadiri sosialisasi kegiatan, rapat menentukan jadwal, rapat mengidentifikasi masalah, intensitas bertanya dan mengajukan ide atau gagasan. Partisipasi petani responden pada tahap perencanaan tergolong dalam kategori sedang yang dimana memiliki persentase $58,33 \%$. Kebanyakan petani turut menghadiri sosialisasi kegiatan, akan tetapi beberapa petani enggan untuk mengikutinya karena terhalang jarak dari tempat tinggal ke lokasi sosialisasi yang relatif jauh. Selain itu, pada saat pertemuan terdapat petani yang tidak mau atau enggan untuk mengajukan pendapat. Hal ini dikarenakan petani kurang dapat mengungkapkan ide mereka dan hanya mengikuti orang yang mereka anggap lebih tahu atau lebih berpengalaman.

\section{Tingkat Partisipasi Pada Tahap Pelaksanaan}

Partisipasi petani pada tahap pelaksanaan kegiatan adalah keikutsertaan petani dalam memberikan kontribusinya dalam kegiatan peningkatan produksi sayuran dan tanaman obat melalui kawasan aneka cabai dalam mengikuti pembinaan, mengaplikasikan inovasi, mengikuti pendampingan, melaksanakan budidaya sesuai SOP dan GAP kegiatan, serta memberikan sumbangan tenaga, uang dan barang terhadap keberjalanan kegiatan. Partisipasi petani responden pada tahap pelaksanaan tergolong dalam kategori sedang yang dimana memiliki persentase $63,33 \%$. Kegiatan yang dilakukan oleh petani sesuai dengan kebutuhan mereka, sehingga menimbulkan kesadaran mereka untuk ikut dan berperan agar dapat memperoleh manfaat untuk menunjang usahataninya, sehingga tujuan yang ingin dicapai terpenuhi, yaitu peningkatan kesejahteraan hidup mereka.

\section{Tingkat Partisipasi Pada Tahap Pemanfaatan Hasil}

Partisipasi pada tahap pemanfaatan hasil yaitu sejauh mana petani merasakan manfaaat atau hasil dari kegiatan peningkatan produksi sayuran dan tanaman obat melalui kawasan aneka cabai dilihat dari intensitas petani menjual hasil produksi, mengolah hasil produksi, serta membagikan ilmu yang didapat dan keuntungan dari segi ekonomi yang di dapat oleh petani dari adanya kegiatan ini. Partisipasi petani responden

pada tahap pemanfaatan hasil tergolong dalam kategori tinggi yang dimana memiliki persentase $38,33 \%$. Hasil produksi cabai dapat 
meningkat sehingga dapat meningkatkan pendapatan petani. Selain itu ilmu yang didapatkan dari kegiatan ini sangatlah bermanfaat dan dapat disebarluaskan kepada petani yang lain. Cabai hasil panen juga dapat diolah sendiri sebagai bumbu dapur.

Hubungan Faktor Faktor yang Mempengaruhi Partisipasi Petani dengan Tingkat Partisipasi Petani dalam Kegiatan Peningkatan Produksi Sayuran dan Tanaman Obat Melalui Kawasan Aneka Cabai
Hubungan antara faktor internal petani dengan tingkat partisipasi petani dalam kegiatan ini dapat diketahui dengan menggunakan uji korelasi rank spearman yang perhitungannya menggunakan IBM SPSS versi 20. Untuk menguji tingkat signifikai terhadap nilai yang diperoleh dengan menggunakan besarnya nilai $t_{\text {hitung }}$ dan $t_{\text {tabel }}$ dengan tingkat kepercayaan $95 \%(\alpha: 0,05)$. Hasil analisis hubungan antara faktor internal petani dengan tingkat partisipasi petani dapat dilihat pada Tabel 1 berikut.

Tabel 1. Hasil Analisis Hubungan antara Faktor Faktor yang Mempengaruhi Partisipasi dengan Tingkat Partisipasi Petani

\begin{tabular}{lcccccccc}
\hline & \multicolumn{9}{c}{ Tingkat Partisipasi Petani } \\
\cline { 2 - 10 } \begin{tabular}{l} 
Faktor Faktor yang \\
\cline { 2 - 10 }
\end{tabular} & \multicolumn{2}{c}{$\begin{array}{c}\text { Perancanaan } \\
\text { Mempengaruhi }\end{array}$} & \multicolumn{2}{c}{$\begin{array}{c}\text { Pelaksanaan } \\
\text { (Y2) }\end{array}$} & \multicolumn{2}{c}{$\begin{array}{c}\text { Pemanfaatan } \\
\text { Hasil (Y3) }\end{array}$} & \multicolumn{2}{c}{$\begin{array}{c}\text { Partisipasi } \\
\text { Total (Ytot) }\end{array}$} \\
\cline { 2 - 10 } & $r_{s}$ & $\mathrm{t}_{\text {hit }}$ & $r_{s}$ & $\mathrm{t}_{\text {hit }}$ & $r_{s}$ & $\mathrm{t}_{\text {hit }}$ & $r_{s}$ & $\mathrm{t}_{\text {hit }}$ \\
\hline Umur (X1 & $0,365^{* *}$ & 2,986 & $0,348^{* *}$ & 2,827 & $0,428^{* *}$ & 3,607 & $0,349^{* *}$ & 2,836 \\
Pendidikan Formal (X2) & $-0,025$ & $-0,190$ & 0,169 & 1,306 & 0,193 & 1,498 & 0,162 & 1,250 \\
$\begin{array}{l}\text { Pendidikan Non Formal } \\
\text { (X3) }\end{array}$ & $0,332^{* *}$ & 2,680 & $0,270^{*}$ & 2,136 & $0,279^{*}$ & 2,213 & $0,332^{* *}$ & 2,680 \\
$\begin{array}{l}\text { Luas Penguasaan Lahan } \\
\text { (X4) }\end{array}$ & 0,037 & 0,282 & 0,160 & 1,234 & 0,090 & 0,688 & 0,232 & 1,816 \\
$\begin{array}{l}\text { Tingkat Pengambilan } \\
\text { Resiko (X5) }\end{array}$ & $0,268^{*}$ & 2,119 & $0,322^{*}$ & 2,590 & $0,324^{*}$ & 2,608 & $0,262^{*}$ & 2,068 \\
$\begin{array}{l}\text { Kealtifan Keanggotaan } \\
\text { Petani (X6) }\end{array}$ & $0,392^{* *}$ & 3,245 & $0,454^{* *}$ & 3,881 & $0,354^{* *}$ & 2,883 & $0,443^{* *}$ & 3,763 \\
\hline
\end{tabular}

Sumber: Analisis Data Primer Tahun 2019

Keterangan:

$\begin{array}{ll}r_{s} & : \text { Koefisien Korelasi Rank Spearman } \\ \mathrm{t}_{\text {tabel }} & : 2,000(\alpha=0,05) \\ \mathrm{t}_{\text {tabel }} & : 2,660(\alpha=0,01) \\ \text { Signifikan } & : \mathrm{t}_{\text {hitung }}>\mathrm{t}_{\text {tabel }}(\alpha=0,05), \text { Ho ditolak } \\ \text { Tidak Signifikan } & : \mathrm{t}_{\text {hitung }}>\mathrm{t}_{\text {tabel }}(\alpha=0,05), \text { Ho diterima } \\ *) & : \text { Signifikan pada } \alpha=0,05\left(\mathrm{t}_{\text {hitung }}>\mathrm{t}_{\text {tabel }}\right) \\ * *) & : \text { Signifikan pada } \alpha=0,01\left(\mathrm{t}_{\text {hitung }}>\mathrm{t}_{\text {tabel }}\right)\end{array}$

Hubungan antara Umur Petani dengan Tingkat Partisipasi Petani

Melihat Tabel 1 menunjukkan adanya hubungan yang sangat signifikan antara umur dengan tingkat partisipasi petani dalam kegiatan peningkatan produksi sayuran dan tanaman obat melalui kawasan aneka cabai, hal itu ditunjukkan dari nilai $r_{s}$ sebesar $0,349 \alpha: 0,05$, dimana nilai $t_{\text {hitung }}$ $(2,836)>\mathrm{t}_{\text {tabel }}(2,000)$, yang berarti Ho ditolak. Hal ini menunjukkan bahwa umur memiki hubungan yang positif dengan tingkat partisipasi petani di dalam menjalankan kegiatan peningkatan produksi sayuran dan tanaman obat melalui kawasan aneka 
cabai. Petani yang memiliki umur lebih muda maka petani tersebut lebih tinggi partisipasinya dalam menjalankan kegiatan dibanding dengan petani yang sudah berusia lanjut. Hal ini sesuai dengan teori yang dikemukakan oleh Hernanto (1984) yang dimana umur petani akan mempengaruhi kemampuan fisik dan respon terhadap hal-hal yang baru dalam menjalankan usahataninya

\section{Hubungan antara Pendidikan Formal Petani dengan Tingkat Partisipasi Petani}

Muchlas (2005) menyatakan bahwa faktor pendidikan formal mempengaruhi dalam berpartisipasi karena dengan latar belakang pendidikan yang diperoleh, seseorang lebih mudah berkomunikasi dengan orang luar dan cepat tanggap terhadap inovasi, namun jika dlihat pada Tabel 1 menunjukkan adanya hubungan yang tidak signifikan antara pendidikan formal dengan tingkat partisipasi petani dalam kegiatan peningkatan produksi sayuran dan tanaman obat melalui kawasan aneka cabai, hal itu ditunjukkan dari nilai $r_{s}$ sebesar $0,162 \alpha: 0,05$, dimana nilai $\mathrm{t}_{\text {hitung }}(1,250)<\mathrm{t}_{\text {tabel }}(2,000)$, yang berarti Ho diterima. Hal ini menunjukkan bahwa pendidikan formal tidak memiliki hubungan dengan tingkat partisipasi petani dalam mengikuti serangkaian kegiatan. Semua petani yang berpendidikan tinggi maupun rendah mempunyai kesempatan yang sama untuk berpartisipasi pada kegiatan ini.

\section{Hubungan antara Pendidikan Non Formal Petani dengan Tingkat Partisipasi Petani}

Melihat Tabel 1 menunjukkan adanya hubungan yang sangat signifikan antara pendidikan non formal dengan tingkat partisipasi petani dalam kegiatan peningkatan produksi sayuran dan tanaman obat melalui kawasan aneka cabai, hal itu ditunjukkan dari nilai $r_{s}$ sebesar $0,332 \alpha$ : 0,05 , dimana nilai $\mathrm{t}_{\text {hitung }}(2,680)>\mathrm{t}_{\text {tabel }}(2,000)$, yang berarti Ho ditolak. Hal ini menunjukkan bahwa pendidikan non formal memiliki hubungan dengan arah positif dengan tingkat partisipasi petani pada di dalam kegiatan ini. Semakin tinggi pendidikan non formal petani maka semakin tinggi pula partisipasinya. Semakin banyak kegiatan-kegiatan pendidikan non formal yang diikuti oleh petani maka petani tersebut akan semakin aktif dalam megikuti kegiatan- kegiatan dalam suatu program dan lebih mudah menerima inovasi yang diterima. Hal ini selaras dengan pendapat dari Soekartawi (1988) yang menyebutkan mereka yang berpendidikan tinggi adalah relatif lebih cepat dalam melaksanakan adopsi inovasi sebaliknya, mereka yang berpendidikan rendah, cenderung agak sulit untuk melaksanakan adopsi inovasi dengan cepat atau dengan kata lain kurang responsif terhadap inovasi atau hal-hal baru.

\section{Hubungan antara Luas Penguasaan Lahan Petani dengan Tingkat Partisipasi Petani}

Kuswardhani (1998) menyatakan bahwa luas sempitnya lahan yang dikuasai akan mempengaruhi anggota untuk mengolah lahan. Petani dengan luas tanah yang lebih luas akan cenderung bersifat aktif dalam mengusahakan lahannya. Pendapat tersebut tidak sama dengan hasil dari penelitian kali ini. Melihat Tabel 1 menunjukkan adanya hubungan yang tidak signifikan antara luas penguasaan lahan dengan tingkat partisipasi petani dalam kegiatan peningkatan produksi sayuran dan tanaman obat melalui kawasan aneka cabai, hal itu ditunjukkan dari nilai $r_{s}$ sebesar $0,232 \alpha: 0,05$, dimana nilai $t_{\text {hitung }}$ $(1,816)<\mathrm{t}_{\text {tabel }}(2,000)$ yang berarti Ho diterima. Hal ini menunjukkan bahwa luas penguasaan lahan tidak memiliki hubungan dengan tingkat partisipasi petani. Petani yang menguasai lahan sempit maupun lahan yang luas mempunyai kesempatan yang sama untuk berpartisipasi dalam kegiatan ini.

\section{Hubungan antara Tingkat Pengambilan Resiko Petani dengan Tingkat Partisipasi Petani}

Melihat Tabel 1 menunjukkan adanya hubungan yang signifikan antara tingkat pengambilan resiko dengan tingkat partisipasi petani dalam kegiatan peningkatan produksi sayuran dan tanaman obat melalui kawasan aneka cabai, hal itu ditunjukkan dari nilai $r_{s}$ sebesar 0,262 $\alpha: 0,05$, dimana nilai $\mathrm{t}_{\text {hitung }}(2,068)>\mathrm{t}_{\text {tabel }}(2,000)$ yang berarti Ho ditolak. Hal ini menunjukkan bahwa tingkat pengambilan resiko memiliki hubungan yang positif dengan tingkat partisipasi petani dalam kegiatan ini. Semakin berani petani mengambil resiko, semakin tinggi pula partisipasinya dalam menjalankan serangkaian 
kegiatan peningkatan produksi ini. Petani penting untuk berani mengambil resiko karena menurut Nelson (1978) Tingkat pengambilan resiko penting karena hampir setiap hari petanipetani dihadapkan pada kondisi usahatani dan hasil produksi yang tidak pasti.

\section{Hubungan antara Keaktifan Keanggotaan Petani dengan Tingkat Partisipasi Petani}

Melihat Tabel 1 menunjukkan adanya hubungan yang sangat signifikan antara keaktifan keanggotaan petani dengan tingkat partisipasi petani dalam kegiatan peningkatan produksi sayuran dan tanaman obat melalui kawasan aneka cabai, hal itu ditunjukkan dari nilai $r_{s}$ sebesar 0,443 $\alpha: 0,05$, dimana nilai $\mathrm{t}_{\text {hitung }}(3,763)>\mathrm{t}_{\text {tabel }}(2,000)$ yang berarti Ho ditolak. Hal ini menunjukkan bahwa keaktifan keanggotaan petani memiliki hubungan yang positif dengan tingkat partisipasi petani dalam kegiatan ini. Petani yang aktif dalam kelompok tani cenderung mempunyai tingkat pengalaman yang lebih daripada petani yang pasif. Hal tersebut sesuai dengan pernyataan Kuswardhani (1998), yang menyatakan status keanggotaan petani dalam kelompok tani akan menentukan terhadap keaktifan anggota dalam berpartisipasi. Anggota yang berperan aktif dalam kelompok tani biasanya memiliki pendidikan serta pengalaman yang lebih daripada anggota pasif.

\section{KESIMPULAN DAN SARAN}

\section{Kesimpulan}

Berdasarkan informasi yang diperoleh di lapang dan pembahasan yang mengkaji mengenai partisipasi petani dalam kegiatan peningkatan produksi sayuran dan tanaman obat melalui kawasan aneka cabai di Kecamatan Kismantoro Kabupaten Wonogiri, maka dapat ditarik kesimpulan sebagai berikut, faktor internal petani faktor internal petani yang berhubungan dengan partisipasi petani dalam kegiatan peningkatan produksi sayuran dan tanaman obat melalui kawasan aneka cabai adalah umur, pendidikan formal, pendidikan non formal, luas penguasaan lahan, tingkat pengambilan resiko, dan keaktifan keanggotaan petani yang dimana setiap petani memiliki karakteristik yang berbeda beda. Tingkat partisipasi petani dalam kegiatan peningkatan produksi sayuran dan tanaman obat melalui kawasan aneka cabai tidak sama pada setiap tahapannya. Pada tahap perencanaan dan tahap pelaksanaan tingkat pertisipasi petani termasuk dalam kategori sedang, sedangkan pada tahap pemanfaatan hasil tergolong dalam kategori tinggi Tidak semua faktor internal petani memiliki hubungan yang signifkan dengan tingkat partisipasi petani dalam kegiatan peningkatan produksi sayuran dan tanaman obat melalui kawasan aneka cabai. Faktor yang memiliki hubungan signifikan adalah umur, pendidikan non formal, tingkat pengambilan resiko, dan keaktifan keanggotaan petani, sedangkan faktor yang memiliki hubungan tidak signifikan adalah pendidikan formal dan luas penguasaan lahan.

\section{Saran}

Berdasarkan hasil penelitian partisipasi petani dalam kegiatan peningkatan produksi sayuran dan tanaman obat melalui kawasan aneka cabai di Kecamatan Kismantoro Kabupaten Wonogiri, maka dapat diajukan saran sebagai berikut, intensitas mengikuti kegiatan pendidikan non formal perlu ditingkatkan lagi dengan cara menyesuaikan kembali jadwal petugas dengan petani, agar petani dapat mengikuti pendidikan non formal secara rutin. Partisipasi petani pada tahap perencanaan dapat ditingkatkan lagi dengan cara meningkatkan kehadiran petani dalam kegiatan diskusi, rapat dan sosialisasi perencanaan kegiatan. Petani yang memiliki umur produktif lebih dilibatkan lagi pada kegiatan ini karena petani yang masuk kategori ini memiliki hubungan yang signifikan dengan tingkat partisipasi sehingga kegiatan dapat berjalan dengan lebih baik lagi.

\section{DAFTAR PUSTAKA}

BPS. 2017. Luas Panen dan Produksi Tanaman Sayuran dan Buah-buahan Semusim Menurut Kabupaten/ Kota di Jawa Tengah, 2015 - 2016. https://jateng.bps. go.id diakses Tanggal 19 September 2018.

Conyers, Diana. 1991. Perencaan Sosial di Dunia Ketiga. Yogyakarta: UGM Press

Direktorat Jenderal Hortikultura. 2015. Potensi, Permasalahan dan Tantangan Pembangunan Hortikultura. Jakarta: Direktorat Jenderal Hortikultura. 
Hernanto, F. 1984. Petani Kecil Potensi dan Tantangan Pembangunan. Bandung: PT. Gramedia.

Kuswardhani, AH. 1998. Hubungan Antara Status Sosial dan Partisipasi Anggota KUD (Studi Kasus di KUD Sawit Kabupaten Boyolali. Skripsi. UNS. Muchlas, M. 2005. Perilaku Organisasi. Yogyakarta: Universitas Gadjah Mada.

Nelson, PV. 1978. Greenhouse: Operation and Management. Virginia: Reston Publishing Company, Inc.

Saptana, A Daryanto, HK Daryanto dan Kunjtoro. 2010. Strategi Manajemen Risiko Petani Cabai Merah Pada Lahan Sawah Dataran Rendah Jawa Tengah. Jurnal Manajemen dan Agribisnis Vol.7(2): 115-131.

Soekartawi. 1996. Pembangunan Pertanian. Jakarta: PT. Raja Grafindo. 